\title{
Vegetation structure, species diversity, and mangrove zonation patterns in the Tanjung Panjang Nature Reserve Area, Gorontalo, Indonesia
}

\author{
Dewi Wahyuni K. Baderan, Ramli Utina \& Nurain Lapolo \\ Department of Biology, Faculty of Mathematics and Natural Sciences, Universitas Negeri \\ Gorontalo, Gorontalo, Indonesia
}

\section{Abstract}

This study aimed to analyze the structure of vegetation, diversity and patterns of mangrove zonation in the Tanjung Panjang Nature Reserve area. Data collection of mangrove vegetation structure was carried out by using the line transect method (plot measuring $20 \mathrm{~m} \times 20 \mathrm{~m}$ ), measurement of environmental parameters that supported mangrove life, and 12 soil samples carried out by laboratory tests. The sample distribution was 18 research sample points. The results showed that mangrove vegetation density both at the level of trees, saplings and seedlings was in the category of total damage with density values at tree level 0.04-0.22 ind/ha), sapling 0$0.07 \mathrm{ind} / \mathrm{ha}$ ), and seedlings $0.02-0.08 \mathrm{ind} / \mathrm{Ha}$ ). The percentage of closure types ranged from $0 \%-38 \%$, meaning that the criteria of damage was rare, which was $<50 \%$, and some were included in the criteria of total damage, which was $0 \%$. The index of mangrove species diversity was sequential starting from the level of trees, saplings and seedlings, which were 0.37-1.53, $0.00-0.31$, and 0.00 , where the tree level diversity index was in the medium category, and the sapling and seedling levels were in the low category.

\section{Article History}

Received 14 October 2018

Accepted 21 December 2018

Keyword

Vegetation,

Diversity,

Zonation,

Mangrove,

Tanjung Panjang

Nature Reserve

\section{Introduction}

Mangrove ecosystem is one of the main potential of coastal areas which plays physical and ecological roles. The physical role is that mangrove protects coastal areas from the threat of erosion, sedimentation and breakwater (Zulkarnaini et al. 2017). Mangroves also protect coastal areas from natural disasters, such as hurricanes and tsunamis (Gedan et al. 2011: Kathiresan and Rajendran, 2005: Kusman et al. 2005: Cochard et al, 2008). In addition, mangroves can retain the habitat of biota association to maintain biodiversity, and has economic potential for forest products, fisheries, and ecotourism (Suwardi, 2013).

Mangroves are spread throughout the world, including Indonesia, which is one of the countries with the largest mangrove forests in the world. Indonesia has the highest level of mangrove diversity in the world with 202 mangrove species. Of these 202 species, 43 species (including 33 species of trees and some shrubs) are true mangrove species, and other species are found around mangrove forests as associated mangrove species (Noor et al. 2012). The 
high level of biodiversity makes mangrove forests an important asset in the perspective of ecological and economic functions (Dahuri, 1996). However, mangroves are not currently seen as an important asset that can be maintained, so that mangrove damage increases every year. This happens because mangrove forests in many places become objects of various development activities, especially ponds. As a result, the mangrove ecosystem continues to experience formation changes. The loss of mangrove areas into ponds is also found in the Gorontalo region.

The Tanjung Panjang Nature Reserve is one example of the largest mangrove area in Gorontalo that has been converted into pond. It is estimated that an area of 16 ha has been opened since 1994. The pond area increased to 297 ha in 2000 and in 2015 the area increased by 7,129 ha (Blue Forests, 2017). This illustrates that the designation of mangrove forests into ponds has increased over a period of 15 years from 2000 to 2015 (Lapolo et al. 2018).

The conversion of mangroves into ponds can cause a decline in the functions and benefits of mangrove forests, especially the loss of mangrove species that will affect coastal productivity and the reduced diversity of species from mangrove ecosystems globally, especially Indonesia.

The study reported in this article aimed to analyze the structure of vegetation, diversity and patterns of mangrove zonation in the area of Tanjung Panjang Nature Reserve. The data collected can be used as one of the supporting data for policy making in reducing mangrove damage in the area.

\section{Materials and Methods}

Research Site

The present study was conducted in the Tanjung Panjang Nature Reserve area located in Pohuwato Regency, Gorontalo, Indonesia, which included three villages namely Siduwonge village, Patuhu village, and Limbula village (Figure 1). Geographically, the site where the study was conducted was located between the coordinates $0^{0} 25^{\prime} 28,93^{\prime \prime}$ - $0^{0} 30^{\prime} 1,93^{\prime \prime}$ North Latitude and $121^{\circ} 44^{\prime} 27,60^{\prime \prime}-121^{\circ} 47^{\prime} 0,44^{\prime \prime}$ East Longitude.

\section{Data Collection}

An exploratory survey method was used in the study. Data were collected in the form of primary and secondary data. Collecting primary data was carried out by identifying all mangrove species using a book (Giesen et al. 2006; Noor et al. 2012), the level of diversity, and the pattern of mangrove zonation using the line transect method. Secondary data collection was from other studies published in journals, Pohuwato Regency Statistics in Figures and other supporting data.

Mangrove vegetation data collection was done by determining the starting point of measurement; a $100 \mathrm{~m}$ transect line was drawn from south to north. On each transect line a plot of observations was made at the tree level. On each mangrove zonation along the transect line was placed a plot with a size of $20 \mathrm{~m} \times 20 \mathrm{~m}$ with limit signs on every $10 \mathrm{~m}$ and alternates to the left and right transects (Kusmana, 1997). The plot was made in the size of $10 \times 10 \mathrm{~m} 2$ for tree groups, $5 \times 5 \mathrm{~m} 2$ for sapling and $1 \times 1 \mathrm{~m} 2$ for seedlings (Bengen, 2004).

Each transect line was determined by two sample plots. In each sample plot, there were individual counts and measurements of tree trunk diameter (dbh) or $1.3 \mathrm{~m}$ from the soil surface were taken, and the circumference of the $d b h$ and the names of mangrove species found in the tally sheet were recorded. For seedlings, the diameter measurements were carried out under the starting part of the discovery of the branch. 

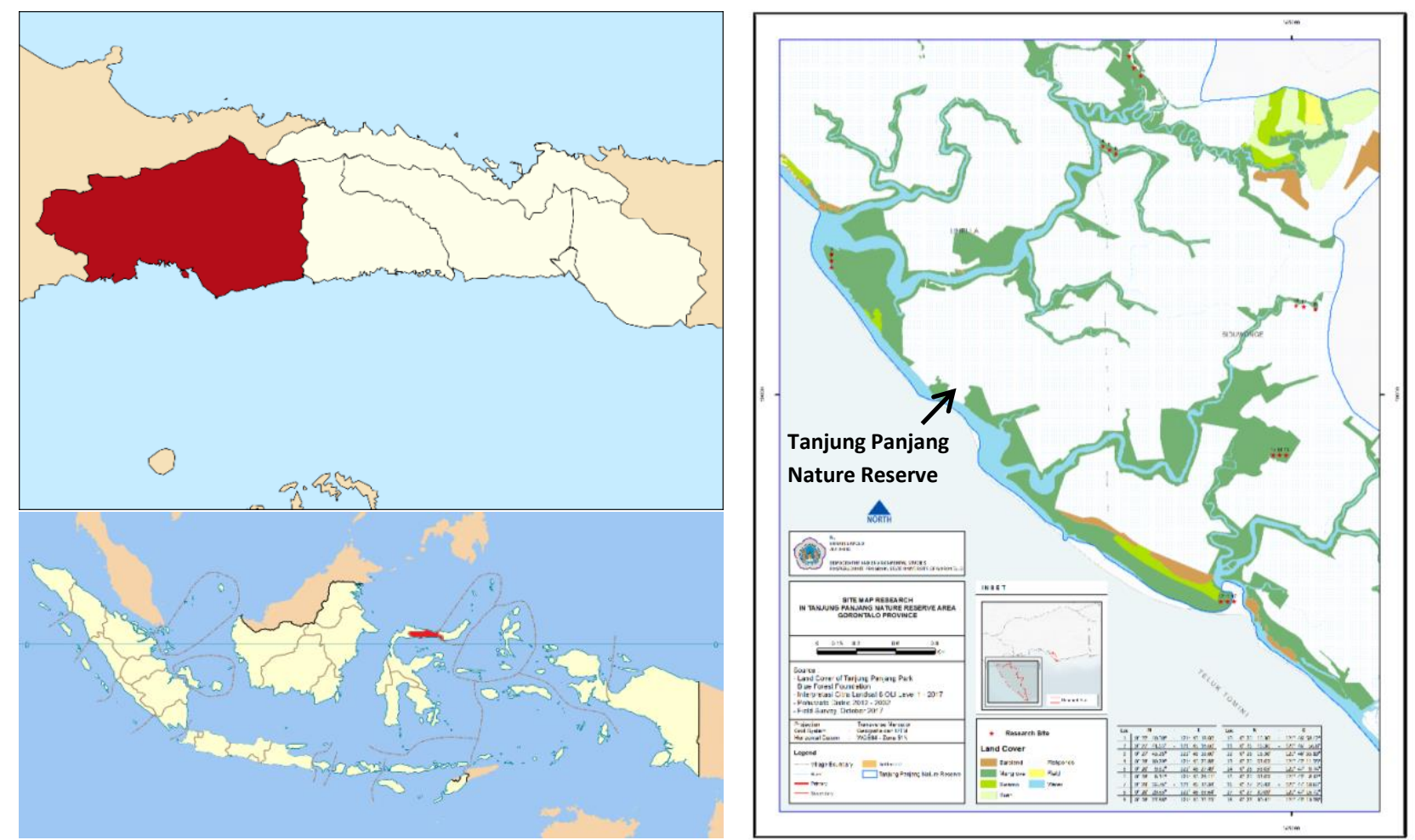

Figure 1. Research sitemap within the area of Tanjung Panjang Natural Reserve of Pohuwato District, Gorontalo Province, Indonesia

\section{Environmental Parameter}

Furthermore, environmental parameters were measured at the same location by taking mangrove vegetation data at each research station. The measurement includes soil $\mathrm{pH}$, soil texture, and soil samples at low tide using core panels made of pipes at 0-30 cm depth (Sara et al. 2014). The aim was to examine soil nutrient content (N, P, K), air temperature, air $\mathrm{pH}$, and salinity.

\section{Results and Discussion}

\section{Species which form mangrove vegetation}

The study found 13 mangrove species, consisting of 11 true mangrove species and 2 associated mangrove species (see Table 1). The mangrove families were Avicenniaceae, Combretaceae, Lythraceae, Meliaceae, Rhizophoraceae, Sonneratiaceae, Aizoaceae, and Convolvulaceae. The true species of mangroves found in the research site were Avicennia marina, Lumnitzera racemosa, Phempis acidula, Xylocarpus granatum, Xylocarpus moluccensis, Bruguiera gymnorrhiza, Ceriops tagal, Rhizophora apiculata, Rhizophora mucronata, Rhizophora stylosa, and Sonneratia alba. For the mangrove types, the associations at the research site were Aturvium portulacastrum, and Ipomea pes-caprae.

Table 1. Mangroves species in the research site

\begin{tabular}{clll}
\hline No & \multicolumn{1}{c}{ Family } & \multicolumn{1}{c}{ Scientific name } & \multicolumn{1}{c}{ Local name } \\
A. & True Mangroves Group & & \\
1 & Avicenniaceae & Avicennia marina & Api-Api \\
2 & Combretaceae & Lumnitzera racemosa & Dulu'-dulu' \\
3 & Lythraceae & Pemphis acidula & Santigi
\end{tabular}




\begin{tabular}{|c|c|c|c|}
\hline 4 & & Xylocarpus granatum & Tambu putih \\
\hline 5 & Meliaceae & Xylocarpus moluccensis & Tambu hitam \\
\hline 6 & & Bruguiera gymnorrhiza & Sala' - sala' \\
\hline 7 & & Ceriops tagal & Tanggere \\
\hline 8 & Rhizophoraceae & Rhizophora apiculata & Bangko \\
\hline 9 & & Rhizophora mucronata & Bangko \\
\hline 10 & & Rhizophora stylosa & Bangko \\
\hline 11 & Sonneratiaceae & Sonneratia alba & Parappa \\
\hline B. & Mangrove Associates Group & & \\
\hline 12 & Aizoaceae & Rhizophora stylosa & . \\
\hline 13 & Convolvulaceae & Sonneratia alba & . \\
\hline
\end{tabular}

Mangrove vegetation structure at the observation station based on the standard criteria for mangrove forest destruction of Kep-MENLH No. 201 (2004) in Baderan (2013) was included in the rare damage and full damage criteria (Figure 2). This was due to the condition of the mangrove forest with $<1000$ (ind / ha) and 0 density, and $<50 \%$ and 0 closing value of species. The density value obtained by each observation station starting from the tree level was 0.04-0.22 ind / ha; the sapling level was 0.00-0.07 ind / ha; and the seedling level was $0.02-0.08$ ind / ha.

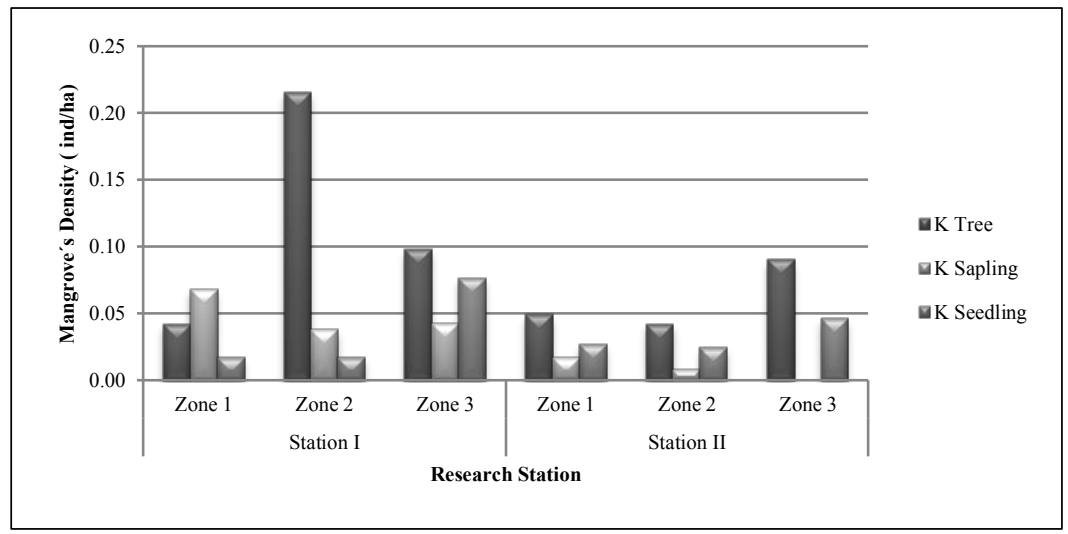

Figure 2. Mangrove's Density in the in the site area

The percentage of the type closure obtained in this study ranged from 0\% -38\% (Table 2). The percentage value of tree level closure was $9 \%-38 \%$, and the sapling rate ranged from $0 \%-37 \%$. This showed that the closure of tree-level mangroves was in the criteria of rare damage $(<50 \%)$, while the closure of the level of mangrove species was total damage $(0 \%)$.

\section{The diversity of Mangrove Species}

The diversity index $\left(\mathrm{H}^{\prime}\right)$ of mangrove species shown in Figure 4 revealed sequential values, starting from the tree level, saplings, and seedlings, which were $0.37-1.53,0.00-0.31$, and 0.00 . The graph shows that the diversity index which is in the medium category is only found at the tree level (1.53) Station II Zone 3, and the others at the sapling and seedling levels are in the low category. Overall, the index of mangrove species diversity in the observation station was in the low category. 


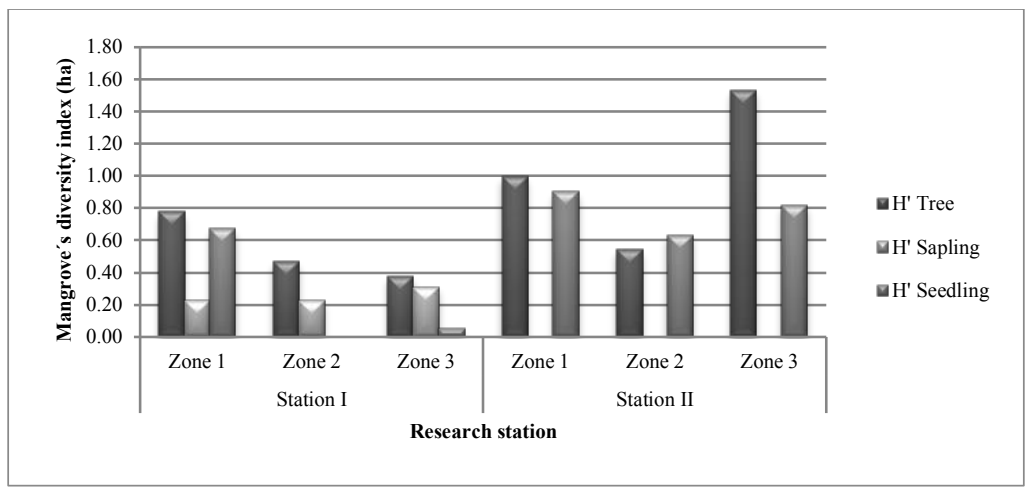

Figure 4. Mangrove's diversity in the site area

Table 2. The percentage of mangrove species closure at the research site

\begin{tabular}{|c|c|c|c|c|c|c|c|}
\hline \multirow[b]{2}{*}{ No } & \multicolumn{4}{|c|}{ Tree } & \multicolumn{3}{|c|}{ Stake } \\
\hline & Species & & $\mathrm{Ci}(\%)$ & Rci (\%) & Species & $\mathrm{Ci}(\%)$ & Rci (\%) \\
\hline 1 & Ceriops tagal & & 3.96 & 44.76 & Ceriops tagal & 0.20 & 79.24 \\
\hline 2 & Rhizophora mucronata & & 3.61 & 40.74 & Rhizophora mucronata & 0.01 & 4.15 \\
\hline 3 & Rhizophora. stylosa & & 0.44 & 4.92 & Rhizophora. stylosa & - & - \\
\hline 4 & Xylocarpus granatum & & 0.11 & 1.27 & Xylocarpus granatum & 0.00 & 0.29 \\
\hline 5 & Xylocarpus mollucensis & & 0.05 & 0.56 & Xylocarpus mollucensis & 0.00 & 1.07 \\
\hline 6 & Bruguiera gymnorrhiza & & 0.43 & 4.87 & Bruguiera gymnorrhiza & - & - \\
\hline 7 & Rhizophora apiculata & & 0.02 & 0.21 & Rhizophora apiculata & - & - \\
\hline 8 & Avicennia marina & & 0.14 & 1.53 & Avicennia marina & 0.04 & 15.25 \\
\hline \multirow[t]{2}{*}{9} & Sonneratia alba & & 0.10 & 1.13 & Sonneratia alba & - & - \\
\hline & & Total & 8.86 & 100.00 & & 0.25 & 100.00 \\
\hline
\end{tabular}

\section{Mangrove Zonation}

Mangrove zonation in the research site grew from the edge of the sea to the land, dominated by Ceriops tagal species in each research site (Figure 5 and Figure 6 ). The zonation patterns were all in a disturbed condition. This was because the shore and the land had turned into ponds. At Station II of Patuhu village, the pond distance from the coastline was only 50 $\mathrm{m}$. This indicated that the conversion of land into ponds in the research site had a negative influence on the formation of mangrove zonation, as well as the physical changes (mangrove habitat).

Mangrove stands at the research site would find it difficult to withstand any forms of physical changes. The outermost physical seas which protected mangrove ecosystems in the mainland or which had become pond areas would largely lose their physical functions as protection from coastal abrasion, erosion and sedimentation. Although there was a new mangrove habitat in the near estuary of tidal flow, changes due to sedimentation rate from the pond may occur.

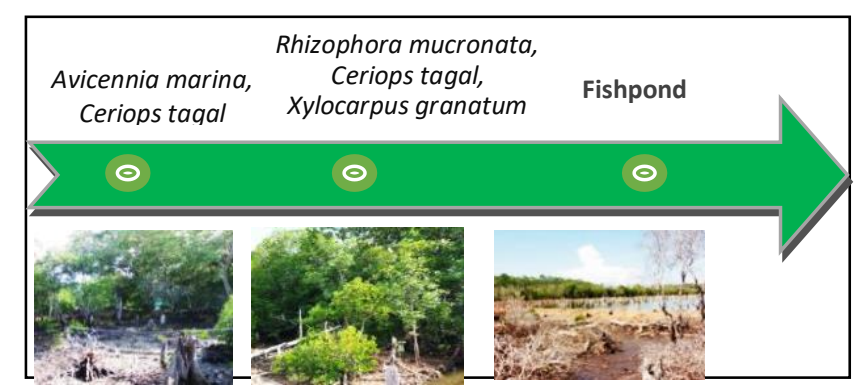

Figure 5. True Mangrove Zonation Pattern in the site area (Station I) 


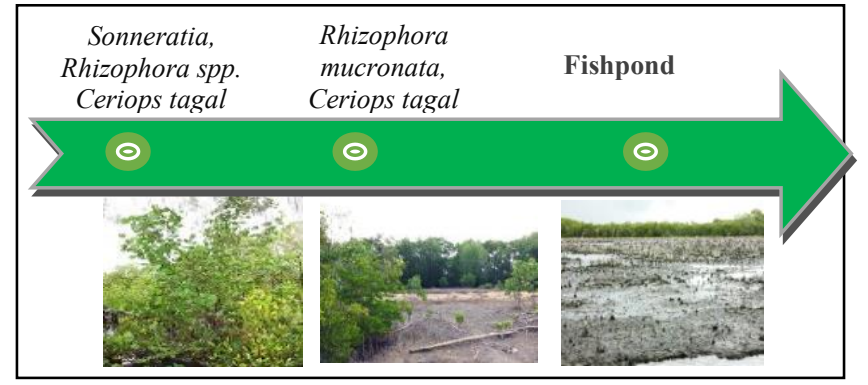

Figure 6. True Mangrove Zonation Pattern in the site area (Station II)

\section{Environmental parameters at the research site}

The environmental parameters measured were mangrove areas and ponds. What was measured was salinity, water $\mathrm{pH}$, temperature, and soil $\mathrm{pH}$ (Table 3 and Table 4). The $\mathrm{pH}$ of the water obtained in the mangrove area ranged from 5.6-7.0. This $\mathrm{pH}$ was in the neutral category. Temperatures ranged from 30.60C-33.30C. Stations I and II zone 1 had soil pH values of 5.2 and 5.6 which were categorized as acids. The $\mathrm{pH}$ value of the soil in several other zones was in the range of 6 . This showed that the soil $\mathrm{pH}$ in the research site was still in the neutral category.

The soil texture found were sandy and dusty clay. At Stations I and II Zone 3 there was a sandy clay soil texture. This texture had several characteristics: coarse sand, did not stick to each other and was not easily formed so that it could be quickly destroyed. Station I and II Zone 1 and 2 had dusty clay soil texture. Some characteristics of this texture were slippery soil, easily fused and could be formed but quickly destroyed.

The soil at the research site was almost entirely textured with dusty clay. This texture could hold water, was hard and did not break quickly. Baderan (2013) contends that the texture of dusty clay soil is suitable for ponds. The soil has high clay content and low sand. High sand content is generally not suitable for ponds, because of its high porosity and low soil binding capacity which can be easily detached when used for building embankments.

The highest salinity obtained in the pond area was in Station II Zone 3 with a value of $23.6 \mathrm{ppt}$. The average value of salinity obtained in all stations was $14.0 \mathrm{ppt}$. The $\mathrm{pH}$ of the water in each zone ranged from 6-7 with an average of 6.5. This value was in the neutral category. The highest temperature parameter in the pond area was found at station I zone 3 , which was $38.50 \mathrm{C}$. The average temperature was $34.90 \mathrm{C}$. The $\mathrm{pH}$ value of the soil ranged from 5-6 with the acid (5) and neutral (6) categories. The average value of soil pH obtained was 5.7 in the acid category.

Table 3. Mangrove Environmental Parameters in the Site area

\begin{tabular}{|c|c|c|c|c|c|c|}
\hline \multirow{2}{*}{ Station } & Zone & Salinity (ppt) & $\begin{array}{c}\text { Water } \\
\mathbf{p H}\end{array}$ & $\begin{array}{c}\text { Temp } \\
\left({ }^{\mathbf{0}} \mathbf{C}\right)\end{array}$ & Soil pH & Texsture \\
\hline \multirow{3}{*}{ I } & 1 & 3.9 & 7.0 & 31.6 & 5.2 & Dusty clay \\
\cline { 2 - 7 } & 2 & 9.1 & 5.6 & 33.3 & 6.1 & Dusty clay \\
\cline { 2 - 7 } & 3 & 22.9 & 6 & 30.6 & 7 & Sandy clay \\
\hline \multirow{3}{*}{ II } & 1 & 5.8 & 6.0 & 31.8 & 5.6 & Dusty clay \\
\cline { 2 - 7 } & 2 & 11.3 & 6.0 & 31.5 & 6 & Dusty clay \\
\cline { 2 - 7 } & 3 & 22.8 & 6.0 & 32.0 & 6 & Sandy clay \\
\hline \multicolumn{2}{|c}{ Average } & $\mathbf{1 2 . 6}$ & $\mathbf{6 . 1}$ & $\mathbf{3 3 . 3}$ & $\mathbf{6}$ & \\
\hline
\end{tabular}


Table 4. Pond Environmental Parameters in the Site area

\begin{tabular}{|c|c|c|c|c|c|c|}
\hline Station & Zona & Salinity (ppt) & $\begin{array}{c}\text { Water } \\
\mathbf{p H}\end{array}$ & $\begin{array}{c}\text { Temp } \\
\left({ }^{\circ} \mathbf{C}\right)\end{array}$ & Soil pH & Texsture \\
\hline \multirow{3}{*}{ I } & 1 & 7.0 & 6.5 & 31.8 & 6.1 & Dusty clay \\
\cline { 2 - 7 } & 2 & 10.0 & 6.0 & 35.0 & 6.1 & Dusty clay \\
\cline { 2 - 7 } & 3 & 16.0 & 7.0 & 38.5 & 6.2 & Sandy clay \\
\hline \multirow{3}{*}{ II } & 1 & 5.0 & 6.7 & 33.0 & 6 & Dusty clay \\
\cline { 2 - 7 } & 2 & 22.6 & 6.0 & 34.7 & 6.1 & Dusty clay \\
\cline { 2 - 7 } & 3 & 23.6 & 7.0 & 36.1 & 7 & Sandy clay \\
\hline \multicolumn{2}{|c|}{ Average } & $\mathbf{1 4 . 0}$ & $\mathbf{6 . 5}$ & $\mathbf{3 4 . 9}$ & $\mathbf{6 . 2 5}$ & \\
\hline
\end{tabular}

The results of the analysis of the Laboratory of Chemistry and Soil Fertility, Hasanuddin University, showed that the percentage value of soil nutrients obtained was higher in the pond area. The highest nutrient was 0.24 which is found in the area of the Station 1 Zone 3 , while the lowest nutrient was in the mangrove area of the Station 2 Zone 3, which was 0.1. The results of the analysis showed that the soil nutrient content in the form of $N, P$, and $K$ obtained in the pond area ranged from $0.18-0.24$, while in mangrove areas only ranged from 0.09-0.21.

\section{Discussion}

Mangrove forests in the Tanjung Panjang Nature Reserve area from the 1990s until now continue to experience damage caused by mangrove conversion function into massive shrimp and milkfish aquaculture. The damage to mangroves resulted in changes in the area of mangrove forests and reduced biodiversity, including the diversity of mangrove species. As previously reported by Damanik and Djamaluddin (2012), in Pohuwato District, 25 mangrove species were found in Popayato, Wanggarasi, Randangan, Marisa and Paguat sub-districts. The study found fewer species, namely 13 mangrove species scattered in the research site. The mangrove species found in the research site grew and developed in one zonation so that it looked different from mangrove zonation in general. The number of true mangrove species found in the study area was 11 species that were dominated by the Rhizophoraceae family including Ceriops tagal and Rhizophora mucronata species, and a small portion of others were from the Meliaceae and Sonneratiaceae families. This amount was less than that in the Langge mangrove area, North Gorontalo Regency which was reported by Baderan et al. (2017), namely, 12 species which were also dominated by the Rhizophoraceae family.

Certain mangrove species were increasingly depleted in the Tanjung Panjang area due to habitat damage. Baderan (2017) asserts that such damage impacts on the livelihoods of communities around mangrove areas, and results in the extinction of various species of flora, fauna and certain biota in the world, as well as in the destruction of the mangrove habitat itself. The loss of mangrove stands means that the parent tree producing seeds is lost. The destruction of most mangrove habitats means a decrease in the area suitable for replanting mangroves.

The density of mangroves in the research site was included in the criteria for rare and total damage, namely, the density of trees / ha ie $<1000$ ind / ha and 0 ind / ha. This is in accordance with the standard criteria for mangrove forest destruction stipulated in the KepMENLH No. 201 (2004) as cited in Baderan (2013), which stated that the dominant research locations fall into the category of total damage. However, there remained mangrove stands 
which could withstand extreme environmental conditions. These mangroves were included in the criteria of rare damage.

The density of mangrove vegetation in most research site both from the level of trees, saplings and seedlings was almost entirely in the category of total damage. This was due to the direct or indirect mangrove damage. Directly, this damage was caused by the activities of people living around the area in converting mangrove areas into ponds. Indirectly, such damage was caused by changes in environmental factors, namely salinity, tides, and soil texture which were not able to support the survival of mangrove vegetation in the area.

Mangrove vegetation density is related to each other, both between trees, saplings and seedlings. Mangroves in the research site were not productive to meet the needs of natural regeneration. This is presented in Figure 3 . It can be seen that the fluctuating value of mangrove vegetation density, indicated by one station in Zone 3 had no sapling vegetation at al. Humaidy (2010) perceived that mangroves in coastal areas that were still productive were characterized by the existence of mangroves in meeting the needs of natural regeneration to meet saplings. Natural regeneration is needed to reduce supply or additions from other mangrove broodstock to be used as mangrove seed stock.

Mangroves at the study site could not naturally increase their area, but with the help of mangrove rehabilitation efforts. However, from the observations presented in Figure 3 it can be seen that the density of the stake or seedlings was in the category of total damage. This requires a relatively long time and requires pre-rehabilitation efforts before direct rehabilitation is carried out to restore the ecological function of the mangrove area.

Environmental parameters also contributed to the level of mangrove damage. Salinity obtained was categorized as not in accordance with the sustainability of mangrove ecosystem life. Juwita et al. (2015) confirms that the optimum limit of mangrove life is around 15 ppt $25 \mathrm{ppt}$, while the tolerance limit ranges from $10 \mathrm{ppt}-35 \mathrm{ppt}$. However, some mangroves, such as the Rhizophora mucronata species are able to tolerate the extreme surrounding environment, so that at the study site there were still mangrove stands found, such as Rhizophora mucronata and Ceriops tagal.

Another factor that influenced low salinity was that land clearing at the research location was very dominating so that mangroves found it difficult to keep growing and developing even in conditions that were suitable for their growth. Generally, the level of salinity in the research site did not support the stability of the mangrove ecosystem, because of several factors that also affected the rate of mangrove damage, such as land subsidence, sedimentation, and sea level rise.

Rahim et al. (2017) also stated that salinity affected the growth and density of mangroves. If the salinity was too high, the growth of mangroves would become stunted. Mangroves are not plants that need a lot of salt but mangroves are salt-tolerant plants. As the study reported, the salinity range for the Torosiaje Jaya region is $20 \mathrm{ppt}-22 \mathrm{ppt}$.

The $\mathrm{pH}$ of mangrove waters at the research site was in the range of 5.6-7.0. The result showed that Station I Zone 3 met the criteria for $\mathrm{pH}$ which was suitable for the sustainability of mangrove life, namely 7. This is reinforced by Zaky et al. (2012), the $\mathrm{pH}$ of the water suitable for mangrove life is 7 , where the value is the optimal $\mathrm{pH}$ for the fulfillment of nutrients in the soil. Unlike the case in the pond area, the average $\mathrm{pH}$ of water obtained was 6.5 , the $\mathrm{pH}$ was higher than the $\mathrm{pH}$ of the mangrove area. Humaidy (2010) asserts that the description of the compound $\mathrm{N}$ (nitrogen) can increase the $\mathrm{pH}$ of the water so that the $\mathrm{pH}$ in the pond area is greater than the mangrove area. The existence of $\mathrm{N}$ can improve the sustainability of the cycle $\mathrm{N}$ so as to maintain the stability of the $\mathrm{pH}$ of the The presence of toxic and metals can reduce 
$\mathrm{pH}$. Humaidy (2010) also explains that the presence of water $\mathrm{pH}$ and soil $\mathrm{pH}$ has values that are not much different, namely 6-7.

Another thing is also confirmed by Zaky et al. (2012), in accordance with Decree No. 51 / MENKLH / 2004, that the pH of the soil suitable for mangrove life was 8 which was the optimal $\mathrm{pH}$ for the fulfillment of nutrients in the soil. The $\mathrm{pH}$ obtained in mangrove areas ranged from 5.2-6.1, and the pond area ranged from 6-7. That is why the $\mathrm{pH}$ of the soil in the mangrove area did not meet the criteria for suitable mangrove living areas. Incompatibility of soil $\mathrm{pH}$ in the mangrove area was due to the lack of soil organic matter such as $\mathrm{N}$ compounds produced from mangrove leaf litter. This is due to the location of the research at each station, and the density of the mangroves included in the criteria of total damage.

Temperature was also one of the environmental parameters that affected the life of mangrove biota. The highest temperature was found in the pond area which ranged between $31.50 \mathrm{C}-38.50 \mathrm{C}$, compared to the mangrove area the temperature was lower which was only 30.60C-33.30C. Temperature pressure was higher in the pond area, because of the openness of the land and without mangrove vegetation cover, causing it to have direct sunlight, whereas in the mangrove area the temperature was lower because it was blocked by the cover of mangrove canopy. This is consistent with the study of Pasongli et al. (2015) which stated that the increase in temperature in the pond area was due to direct sun exposure.

The optimum temperature for aquaculture biota was only around $270 \mathrm{C}-320 \mathrm{C}$ with a life tolerance of $160 \mathrm{C}-360 \mathrm{C}$. While the temperature in the mangrove area was slightly lower than the pond, the temperature was not suitable for mangrove sustainability. Juwita et al. (2015) stated that the optimum temperature limit for mangrove growth ranged from 290C$300 \mathrm{C}$. This would affect the photosynthesis process and the process of mangrove growth would be hampered. Thus, the temperature at the research site was not suitable for mangrove growth.

Other conditions that affected the high content of soil nutrients in the pond area were the use of Phonska fertilizer containing N, P, and K content. The application of N, P, K fertilizer was aimed at increasing the production of ponds. The results of the analysis of laboratory tests showed that soil samples at Station I Zone 3 had $\mathrm{N}$ content of $0.17, \mathrm{P}$ ie 24.3 and $\mathrm{K}$ ie 16.52. The content of compounds $\mathrm{N}, \mathrm{P}, \mathrm{K}$ in this pond area sought to support the growth of phytoplankton which was a natural feed from shrimp and milkfish cultivated in the pond. This was confirmed by Pamungkas's research (2011) which showed that the use of fertilizers containing $\mathrm{N}, \mathrm{P}$ and $\mathrm{K}$ was very necessary for the growth of phytoplankton. This means that the provision of fertilizer can increase the number of phytoplankton.

Unlike the case in the mangrove area, the low soil nutrients ( $N, P$, and $K$ ) in the region were influenced by vegetation density and cover which were categorized as damaged, resulting in low decomposition of the resulting mangrove leaf litter. This is because most of the research sites located in the Tanjung Panjang Nature Reserve area had been damaged, causing the diversity and density of mangroves to be in the low category compared to the condition of the mangrove ecosystem that remains good. Other conditions at Station II Zone 1 showed higher soil nutrient content compared to Zones 2 and 3 . This was because soil samples carried out by laboratory tests are from the species of Avicennia marina mangroves.

It was concluded that mangrove vegetation density both at the level of trees, saplings and seedlings was in the category of total damage at the tree level ranging from $0.04-0.22$ ind / ha), saplings ie $0-0.07$ ind / ha), and seedlings $0.02-0.08$ ind / ha ) The percentage of closing types ranged from $0 \%-38 \%$. At the tree level it ranged from $9 \%-38 \%$, included in the criteria for rare damage, namely $<50 \%$, while at the sapling level ranged from $0 \%-37 \%$, 
included in the criteria of total damage ie $0 \%$. The index of mangrove species diversity was sequential starting from the level of trees, saplings and seedlings, which were $0.37-1.53,0.00$ - 0.31, and 0.00, where the tree level diversity index was in the medium category, and the sapling and seedling levels were in the low category. It is necessary to restore conservative mangrove and restocking habitats in a sustainable manner, as well as the arrangement of mangrove areas in the research site by making efforts to rehabilitate the area (mangrove planting), namely the improvement of green belt from the coastline as far as 200-300 m with the species suitable for zonation, and $100 \mathrm{~m}$ on the dominant river bank Rhizopora mucronata.

\section{Conclusion}

Mangrove vegetation density both at the level of trees, saplings and seedlings was in the category of total damage with density values at tree level 0.04-0.22 ind/ha), sapling 0$0.07 \mathrm{ind} / \mathrm{ha}$ ), and seedlings $0.02-0.08 \mathrm{ind} / \mathrm{Ha}$ ). The percentage of closure types ranged from $0 \%-38 \%$, meaning that the criteria of damage was rare, which was $<50 \%$, and some were included in the criteria of total damage, which was $0 \%$. The index of mangrove species diversity was sequential starting from the level of trees, saplings and seedlings, which were 0.37-1.53, 0.00-0.31, and 0.00, where the tree level diversity index was in the medium category, and the sapling and seedling levels were in the low category.

\section{Acknowledgements}

The authors would like to sincerely thank particular individuals and institutions that have contributed to this research, namely, the Postgraduate Program on Population and Environment Studies, Gorontalo State University, which has provided administrative support for this research; Center for Study of Coastal Ecology and Local Wisdom of Gorontalo State University; and Blue Forests which has provided supporting data and references for this research; government officials of Siduwonge, Patuhu, and Limbula Villages, Randangan District, Pohuwato Regency, Gorontalo Province, and BKSDA; as well as the field research team that has helped collect research data.

\section{References}

Baderan, D.W. (2013). Economic Valuation Model as the Basis for Mangrove Forest Rehabilitation in Coastal Areas of Kwandang District, North Gorontalo Province, Gorontalo Province. Dissertation. Postgraduate Program of the Faculty of Geography, Gajah Mada University, Yogyakarta.

Baderan, D.W. (2017). Spatial and widespread distribution of mangrove forest damage in the Kwandang Coastal Area North Gorontalo District Gorontalo Province. GeoEco. 3(1) : 2460-0768.

Baderan, D.W., Rahim, S., Kumaji, S.S (2017). Structure of Vegetation, Biomass, and Carbon stock of Langge Mangrove Forest, North Gorontalo Regency, Gorontalo Province (Research Report). Australian Journal of Basic and Applied Sciences. 11 (14) 48-57.

Blue forests. 2017. Biophysical and Socio Economic Mapping for the Restoration of Tanjung Panjang Natural Reserve. Reports on the mapping of the Tanjung Panjang Natural Reserve survey, ROAM Program. Supported by IUCN, Thailand. 
Bengen, D.G. (2004). Technical Guidelines for Introduction and Management of Mangrove Ecosystems. Bogor Coastal and Marine Resources Study Center. Bogor.

Brower, J.E., Jerrold H.Z., Car I.N.V.E. (1990). Field and Laboratory Methods for General Ecology. Third Edition. Wm.C.Brown Publisher, USA, New York.

Cochard, R. ranamukhaarachchi. S. Shivakoti. GP, Shipin, OV, PJ. And Seeland. K, (2008). The 2004 tsunami in Aceh and Southern Thailand: A Review on Coastal Ecosytem. Wave hazard and vulnerability. Perspectives in Plant Ecology. Evolution and Systematics. 10: 3-40.

Dahuri, R., J. Rais, S. P. Ginting, and M. J. Sitepu, (1996). Management of Integrated Coastal and Ocean Management Resources. PT. Pradnya Paramita, Jakarta.

Damanik, R, and Djamaludin R. (2012). Atlas Mangrove Tomini Bay. Mangrove Condition Survey Gulf of Tomini Program SUSCLAM (Sustainable Coastal Livelihoods and Management Program). Gorontalo.

Gedan, KB, Kirwan. ML, Wolanski. E. Barbier, EB and Silliman. BR. (2011). The Present and Future Role of Coastal Wetland Vegetation in Protecting Shoreline: Answering Recent Challenges to the Paradigm. Climatic Change. 106: 7-29.

Giesen W., Wulffraat S., Zieren M., Scholten L. (2006). Mangrove guidebook for southeast Asia. Bangkok: Rap Publication, Food and Agriculture Organization of the United Nations Regional Office for Asia and the Pacific.

Humaidy D. (2010). A Study on the degradation of mangrove ecosystem for rehabilitation in the coastal area of Kasemen subdistrict, Serang city. (Thesis). Department of Water Resources Management, Faculty of Fisheries and Marine Sciences, Bogor Agricultural University, Bogor.

Juwita, E., Soewardi, K., Yonvitner. (2015). Habitat Conditions and Mangrove Ecosystems in Simpang Pesak District, East Belitung for Shrimp Pond Development. Journal of Humans and the Environment. 22(1): 59-65..

Kathiresan Rajendra K and N, (2005). Tsunami Coastal Mangrove Forest mitigated. Estuarine. Coastal and Shelf Science. Journal of Experimental Marine Biology and Ecology, 234: 255-273.

Krebs, C.J. (1989). Ecologycal Methodology. Harper Collins Publisher Inc, New York.

Kusmana, C. (1997). Suryvey method for vegetation. Institute of Agriculture, Bogor. Bogor.

Kusman C. S. Basuni, S. Wilarso. Ichwandi I., O. Haridjaja. A. Salah and Samsuri, (2005). Directives for Mangrove Forest and Coastal Forest Rehabilitaiton and tsumani in Earthquake Disaster Areas in the Provinces of Nanggroe Aceh Darussalam and North Sumatra. Journal of Tropical Forest Management. 11(2) : 70-84.

Lapolo, N., Utina R, Baderan DWK. (2018). Diversity and density of crabs in degraded mangrove areas at Tanjung Panjang Nature Reserve in Gorontalo, Indonesia. Journal of Biodiversity. 19(3) : 1154-1159.

Noor, Y.R., Khazali M., Suryadiputra I.N.N. (2012). Guide to Introduction to Mangroves in Indonesia. Third print. Wetlands International Indonesia Program. Bogor.

Pamungkas, N A. (2011). Development of Phytoplankton Abundance with Liquid Organic Fertilizer. Periodic Fisheries. 39(1): 79-90.

Pasongli, H., Dirawan, G D., and Suprapta. (2015). Zoning of Pond Suitability for Vaname Shrimp Cultivation Development (Penaeus vannamei) on Water Quality Aspects in Todowongi Village, Jailolo District, West Halmahera Regency. Bioeducation Journal. 3(2): 324-335. 
Rahim, S, Baderan, DWK, Hamidun, S. (2017). The Density, Composition and Mangrove Forest of Torosiaje Jaya Village, Gorontalo, Indonesia. Bonorowo Wetlands. 7(1): 38-42.

Barru South Sulawesi. Thesis (Online). Department of Biology, Faculty of Mathematics and Natural Sciences, Hasanuddin University, Makassar. Retrieved on 3 January 2018.

Zaky, A R., Suryono, C A., Pribadi, R. (2012). Study of Mangrove Land Conditions in Bedono Village, Sayung District, Demak Regency and Mangunharjo Village, Tugu District, Semarang City. Journal of Marine Research. 1(2): 88-97.

Zulkarnaini, Z. Saam, V. Amrivo, and D. Miswadi. (2017). Community Structure and Economic Evaluation Mangrove Village In Bengkalis District. International Journal of Oceans and Oceanography ISSN 0973-2667. 11(1): 63-74. Retrieved on 3 January 2018. 